\title{
A Study of the Concept of Utopia in Hakim Sanai's The Walled Garden of Truth and Thomas More's Utopia
}

\author{
Sana Mahmoudi (Corresponding author) \\ M.A in English Literature, Islamic Azad University -Arak Branch, Arak, Iran \\ 61766-1-3164, PD Box: 61335-4694, Iran \\ Tel: +989380313202 E-mail: sanamahmoudi98@gmail.com \\ Fatemeh Azizmouhamdi \\ Department of English Literature \\ Islamic Azad University, Arak Branch, Arak, Iran \\ Tel: +989366612714 E-mail: f-azizmohamadi@iau-arak.ac.ir
}

Received: 05-08-2013

doi:10.7575/aiac.ijalel.v.2n.6p.161
Accepted: 04-09-2013

Published: 01-11-2013

URL: http://dx.doi.org/10.7575/aiac.ijalel.v.2n.6p.161

\begin{abstract}
Two great literary works in English and Persian Literature; Thomas More's Utopia and Hakim Sanai's The Walled Garden of Truth display number of striking similarities, in addition to some prominent differences. This study tries to highlight the similarities and the differences between these two work; therefore, authors' writing style, mood, characterization and perspective are compared. The results show that both works used journey, narrator, secluded island and priority of description over story narration, which are the key characteristics of literary utopias, as the key methods of their writings. Meanwhile the ideas which each author attempts to impart to his readers differ greatly from each other. More's Utopia presents detailed description of England social organization and Sanai's description of utopia (The City of God) is based on ethical and mystical notions of Islam.
\end{abstract}

Keywords: Utopia, The City of God, Literary Utopia, Narrator, Seclusion, Journey, Dream and Description

\section{Introduction}

The construction of imaginary worlds, free from difficulties that beset us in reality, takes place in one form or another in many cultures. Such images are embedded in origin and destination myths, where the good life is not available to us in this world but is confined to a lost golden age or a world beyond death (Levitas, 2010: 1). In the ideal society prejudice, war, ignorance, poverty and corruption have no place and it is filled with justice, peace, knowledge and security.

According to White (1955), Utopias are distinguished from all other forms of literature by their patent idealism. They are ideal in both of the common senses of the word. Negatively, they are ideal in that they are deliberately non-real; and, positively they are ideal in that they portray an exemplary pattern of culture. These two kinds of idealism are implicit in the word "utopia" itself, which may refer both to an outopos or no place and to aeutopos or place where all is where. Sir Thomas More, the coiner of the term, seems to have taken it in both senses. (p.ix)In his Latin book "Utopia" (1516) More describes the ideal social state in a faraway land secluded from the rest of the world. Although More was the creator of the term "utopia", Plato's Republic is arguably the first Utopian work of literature. Republic offers the necessary steps for the creation of the perfect Greek city-state. In Persian and Islamic Literature, Abu Nasr al-Farabi (c.870-950), "The father of Islamic Neo-Platonism", was the first philosopher to write about ideal city. In his work, AlMadina al-Fadila, Farabi describes city-state of Medina under the rule of the prophet Mohamed as the best example of ideal society. Farabi's work is a significant early contribution to sociology and political science in Islamic world. Thorough out history many other great examples of utopian literature have been created around the world; Among these Utopias we find in most cases searching analyses of current social situations, lucid and fascinating anticipations of a better or perfect society to come, and a presentation of instruments and principles of social progress (Hertzler,1992:2).

\subsection{Types of Utopia}

In terminology, a utopia represents a fanciful projection of a perfect society. Several fundamental characteristics identify the utopian genre of social thought and action. However, the utopian mode has varied in both form and content through history. Farzad Ghaemi(2007) in his paper "Types of Literary Utopia in Persian Classical Literature" offers interesting categories for utopian literary works; he divides the works about utopian societies in three different categories of " Mythical, philosophical and literary utopias". This paper follows his categorization to present different examples of utopian literary works around the world and portray better picture of why More's utopia and Sanai's The City of God, although so different can be compared and considered in the same category. 


\subsubsection{Mythical Utopias}

The signs of mythical utopias can be found in mythology. They show the idealized past of mankind or a paradise within the mythical history of a nation. The oldest account of a mythical utopia can be found in Greek tradition. Mary Ann Beavis (2006) writes "that the oldest account of a mythical utopia in Greek tradition (c.750 BCE) is found in Hesiod's Works and Days (106-200). According to Hesiod, the gods and humanity sprang from the same (unidentified) source. The Olympian God created the human race that lived in a golden age ruled by the Titan Kronos. The first generation of human beings lived a joyful, ageless life, feasting and enjoying the bounty of the earth, "rich in flocks and loved by the blessed Gods". When they died, it was as if they had merely fallen sleep, and their spirits lived on as kindly guardians of humanity." (p.10).

In Renaissance mythology, the concept of Arcadia was introduced as utopia; the term was inspired from Greek mythology. According to Greek mythology, Arcadia was a home of God of jungle and the nymphs and other spirits of nature lived there. Arcadia became a symbol of pastoral simplicity in Renaissance. It was associated with bountiful natural splendor; harmony and its residence were mostly shepherds. They were often regarded as having continued to live after the manner of the Golden Age, without the pride and greed that corrupted other regions. Sir Philip Sidney's Countess of Pembroke's Arcadia (1590) portrays the concept of arcadia brilliantly.

The oldest accounts of utopia in Persian Mythology can be found in Alborz Mountains, the highest mountains of west Asia, which is located in northern Iran and is considered as a holy place by ancient Iranians. Many parts of Avesta such as Zamyad Yasht ("Hymn to the Earth") and Vandidad, consider Alborz Mountains as a holy place. They believed that spirit of dead people cross a bridge in mountain to reach other world. The first prototypes of utopia were created there and their descriptions were based on man's understanding of heaven. According to Zoroastrian beliefs, Ahura Mazda (the lord of light and wisdom) built a magnificent resting place for Izad Mehr on top of the Alborz Mountain where there is no night and darkness or any disease or destruction.

Ferdowsi also writes about utopia in Shahnameh "The Book of Kings". According to Ferdowsi, Siavash built a city called "Siavashgard" or sometimes called "Kang Dazh" which was like fortress and all its residence were living in prosperity.

Var Jam Kard, a city built by King Jamshid is another example of utopia in Persian mythology. According to VandidadFargard 2, when the population of mankind grew King Jamshid built the city in order to save Aryan race.

1.1.2 Philosophical Utopia

Philosophical utopias only focus on principles and politics of ideal state and their writers try to highlight the correct ways for mankind to be happy and prosperous in their communities. They lack the element of storytelling and they are more instructive rather than entertaining. The ability to imagine a society and a culture that would represent ideals of human lives is the foundation upon which all utopian philosophies of social and political arrangements are based. We can say that the idea of utopia originated in the ancient world by man's desire to create an ideal society. The first examples of philosophical utopias can be found in ancient Greece, where politics and philosophy meant the same thing. The two great examples of utopian society based on philosophy are Plato's Republic and Aristotle's Politics. Plato's "Republic" is the expression of the ideal of a classical philosopher, the representative of the highest culture of his age, writing in his prime and consequently representing the best secular thought of the age (Hertzler,1922:99). Aristotle also discusses various theoretical and actual models of perfect society in his Politics. It also provides analysis of the types of political community that existed in his time and shows where and how these cities fall short of the ideal community of virtuous citizens. Aristotle's politics does not mainly report or observe the politics of Greek city-states, but rather analyses the origins and characteristics features of politics (Swanson and Corbin, 2009:2).

Among Islamic philosopher, Farabi is the first philosopher who wrote about utopian society. His Al-Madina Al-fadila (The Virtuous City) is the best example of political science in Islamic philosophy. While this work undoubtedly was influenced by Plato's Republic, its theology unlike its politics was beyond the Plato's ideas. Farabi's understanding of society is influenced by Islamic society's concepts. Unlike Plato who only considers the Greek city state as an ideal society, Farabi believes that perfect society can include many nations under its wing as long as it has competent leader to control those communities. According to him, the only person competent enough to lead such huge society is prophet himself who has guidance of God. Farabi's ideas regarding utopian society was wide and extended to major Islamic philosophers such as Ibn Sina and Khaje Nasir aldin Tusi. (Asil, 1371: 102-105) Ibn Sina believed that the key of success in one society is division of social work. Ibn Sina divides utopian society into three classes: first the leaders, second the crafts men and third the guards. Each class has its own leader and if every participant do their duties, the system will be perfect (Asil, 1371:107-113).

As it was stated before, all philosophical utopias focus on principles and policies of an ideal state and each philosopher base on his culture, religion or belief offer a set of principles but the common concept between most philosophers, is the importance of society as a whole and its need to have a wise leader.

\subsubsection{Literary Utopia}

Literary Utopia presents its author's ideas and believes regarding ideal society through a story. Whether those concepts philosophical, religious or mythical, they are told through characters experiences and observations. The main characteristics of literary utopias are Journey (each character goes through a long and difficult journey to reach utopia), Geographical Seclusion ( all utopias are located in faraway lands that is hidden from others), high value of description ( literary utopias focus on city and people's physical details), having a narrator (in all literary utopias a witness tells the story through conversation he / she has with others) and Dream like vision ( all literary utopias are places that have dream like qualities). 
The City of God by Saint Augustine is the first example of literary utopia. It was one of the most influential works of the Medieval Ages and offered a theory that people need government because they are not able to reach salvation alone. Augustine introduced two societies, "The City of God" which only the chosen ones lived there and "The City of Man" that was a place for damned. Scholars believe that these "cities" are symbolic presentation of faith and disbelieve. Saint Augustine believed that these two sources existed from the man kind creation and only ends with the Second Coming of Christ.

The concepts offered by Saint Augustine in The City of God had a great influence on Thomas More's Utopia. In his Book II of Utopia, More describes a pagan and communist city-state in which people and community were entirely governed by reason. Scholars believe that The order and dignity of More's state was intended to provide a notable contrast with the unreasonable policies of Christian Europe, divided by self-interest and greed for power and riches, which More described in Book I. More uses a traveler called Raphael Hythloday as witness of the ideal society and all the description regarding utopia is presented by his observation.

A hundred years after Thomas More ushers in the new literary genre of Utopia, Francis Bacon writes his New Atlantis. Whereas More's work presents a detailed description of a social organization, Bacon's text focuses less on the politics of the society and more on a particular aspect of the societal organization, the scientific community (Dragomir, 2011:2). Bacon starts New Atlantis with the description of a ship lost at sea and a sea captain, who accidently finds an island called Bensalem, recalls his experiences in that island and its enlightened society. Bacon tries to compare the society of that time with a place that existed in Bacon's vision of what the society should have been instead.

In Persian Literature, Nezami Ganjavi is among the first authors who introduced utopia in his work. he is considered as the greatest romantic epic poet in Persian literature that looked for justice and ideal society all his life. Among his five great books ("Panj Ganj" or "Khamsa"), Makhzan al-Asrar (The Treasury of Mysteries) is a great example of literary utopia. It is divided into twenty chapters called maqalas, each with the same structure: first, a theoretical part, then an exemplary story and finally a conclusion attached to the story. One of the famous stories in Makhzan al Asrar is a story about ideal society that Alexander discovers. In Nezami's utopia, government doesn't exist and society is built on truth and God's obedience. He believes in man's integrity and good nature and according to him, governments take advantages of this quality and become barrier for peace and cooperation in society.

The name of "Nowhere Land" (Utopia) as a paradise on earth was first introduced by Shahab ad-Din Suhrawardi (11551191) in his essay "Awaz-e par-e Jebrail" (The Chant of the Wing of Gabriel). Suhrawardi places his utopia behind the mythical mountain of "Ghaf". According to Suhrawardi, reaching "Nowhere Land" requires spiritual and inner journey. Once you are spiritually prepared, gates of epiphany open and all of the barriers and curtains fall and you become able to see that promised land. The features, Suhrawardi offers for his nowhere land is not similar to materialistic cities. It more has resemblance to heaven and paradise. Suhrawardi's ideal city is described through the poet encounter with an old man who came from utopia. But he is not the first writer to use this method. Before Suhrawardi, it was Hakim Sanai that used the character of old man in two of his works to introduce a perfect place called The City of God. In "seirol ebad elal maad" and "The walled Garden of Truth", Sanai's old man acts as an active mind that guides us through right living path. In "The walled Garden of Truth" the main character is the poet himself that meets a wise man who has come from perfect world to guide him to salvation. Sanai's utopia, inspired by Islamic and Sufi ideas, presents a world that is otherworldly and cannot be reached unless person reaches perfection as mankind.

This article attempts to portray and analyze the characteristics of utopian society (ideal society) in two great literary works in English and Persian Literature; Thomas More's Utopia and Hakim Sanai's The Walled Garden of Truth. As it was stated earlier, Although More's ideal society presents detailed description of England social organization and Sanai's description of utopia is based on ethical and mystical notions of Islam, surprisingly both authors have some similar approaches in portraying their ideas about utopia and both works can be classified as literary utopia. The purpose of this study is to highlight the similarities and the differences of author's writing style, mood, characterization and perspective.

\section{Literary Background}

\subsection{Thomas More}

Sir Thomas More has been variously described as 'the most attractive figure of the early sixteenth century', 'the voice of conscience' of the early English Reformation and 'one of the three greatest figures of the English Renaissance'. He was a scholar, lawyer, theologian, statesman and eventual martyr, whose influence was less on the development of the Reformation in England as upon creating a particular genre of futuristic and idealistic writing about society. His most famous book, Utopia, has come to be accepted as an everyday term in the English language and 'utopian' is often used to refer to an idea or concept that is idealistic and highly desirable (Watson, 1994:1).

Born in 1477 in the heart of London, More learned service to his country as part of a long established family tradition. On both his mother's and father's side, civic service was a way of life. More's father was a well-known and respected lawyer, then a judge. There in London, More learned the importance of citizens' vigilant involvement in government, a lesson he would appreciate even more deeply after studying the Greek and Roman philosophers and statesmen (Wegemer, 2001:01). He used his studies and life experiences in court to create the ideas of civic humanism and the Ideal of Peace.

As stated before, More was very involved in public affairs, he became a member of Parliament in 1504. Ten years later he became Master of Requests in Henry VIII court, and then he was selected as treasurer of the exchequer (1521), and 
chancellor of the Duchy of Lancaster (1525). After fall of Thomas Wolsey in 1529, he was appointed Lord Chancellor. More displayed a primitive virtue and simplicity in his position. He was very committed to Catholic faith, so, he witnessed with displeasure the steps that led Henry to the final schism with Rome. In 1532 he resigned the chancellorship. His refusal to accept Henry as new head of the Church of England, led to his sentence for high treason and his death on July 71535 .

More lived in one of the most revolutionary periods of all times, called by some the Early Modern Period and by others the English Renaissance, the "rebirth" of the exhilarating classical ideal which later became known as civic humanism. This ideal focused upon a person's duties and possibilities in building up the earthly city as the natural sphere of human greatness (Wegemer, 2001:3). More wrote his famous work "Utopia" base on this concept.

Sir Thomas More wrote Utopia while on an extended diplomatic mission to Bruges and published his work in 1516. It is the story of the mythical island called No Place (Utopia), where the people get along through their virtue, reason, and charity. The vices of greed and jealously have been engineered out of the society by ordaining that everyone wear the same clothes and that houses be exchanged every ten years. More based his allegory of England on Plato's Republic, among other classical (and biblical) sources. More's Utopia is a celebration of the potential for human virtue and pleasure on Earth and thus a seminal work of humanist literature (Galens, 2012: 179).

\subsection{Hakim Sanai}

Sanai is regarded as the pioneers of Sufism and mysticism in Persian literature. He is one of the greatest speakers of Persian language, influencing the poetry of his successors and has brought about the diversity and modernity in the words of poets after him (Izadi Lybidi and Moghaddas, 2012:1117). Sanai was born at Ghaznain in Afghanistan, and, while yet young, became one of the most learned, devout, and excellent men of the age which he adorned. His praise was on every tongue; for, in addition to his accomplishments in the Sufi philosophy, he possessed a kind and benevolent heart, delightful manners, and a fine taste for poetry. Mulavi Jelaluddin, an eminent scholar, and a most distinguished Sufi, considered himself inferior to Sanai; he says, "Attar was the soul itself, and Sanai its two eyes; but I come after both Sanai and Attar" (Ouseley \& Reynolds, 1846: 184).

Sanai's poetry mainly expresses the philosophical, mythical and ethical ideas of Sufism. The religious imprint of Sanai's work manifests itself among other things in an extensive use of quotations and motifs derived from the Quran, the traditions and religious role in general, such as the lives of the prophet $\mathrm{s}$ and acts and sayings of the great mystics of Islam. (De Brujin ,1983:38). From young age, Sanai was attached to the court of Bahramshah, writing praises for the king. Then after encounter with a dervish and hearing his remark about mistake of serving kings instead of God, he secluded himself from the world and gave up all the luxuries and vanities of the court. He went on pilgrimage and when he returned, started to write his most celebrated work "The Walled Garden of Truth". Sanai's most famous works are The Karnama Balkhi (primarily topical poem) and The Sairal ibad ilal maad (his second mathnavi in which Sanai established himself as a religious poem) and The Walled Garden of Truth (a collection of poems, prose fables and aphorism). The Walled Garden of Truth is one of the earliest sufi works, which attempt to discover the truth of man. The work expresses the poet's ideas on God, philosophy, reason and love (Bullock, 1992: 118).

Sheikh Sanai died on 576A.H, 1180 A.D, and was buried at Ghaznin, where his tomb is visited by pilgrims, and is called the "Mecca of Ghaznin" (Ouseley, 1846:187).

\section{Discussion}

Each author has specific qualities for its ideal society. "There is always a close link between the invented utopia and the social environment in which its author is situated, the alternatives offered, the representation of a radically different society, invariably springing from a lucid critique of what the present is for the writer. Indeed, the essence of utopia lies precisely in its inherent ambiguity, in its play between a design which is not-yet-real and the reality which the design contests" (Fortunati \& Trousson, 2000:635). No matter how different the ideas of each author, surprisingly one can always find the similar characteristics for utopia which are rooted in mankinds' common instincts and desires. In this section we will highlight the similarities and differences between Thomas More's "Utopia" and Hakim Sanai's "The City of God".

One interesting similarity between Utopia and The City of God is their authors' way of presentation and portrayal of their ideal society through an eye witness. In Thoma More's work, a traveler named Hythloday finds the island of Utopia accidently and all the characteristics of utopia are presented based on his observation.

"If you had been in Utopia with me and had seen their laws and rules, as I did, for the space of five years, in which I lived among them and during which time, I was so delighted with them that indeed I should never have left them if it had not been to make the discovery of that new world to the Europeans, you would then confess that you had never seen a people so well constitute and as they" (Utopia, 2007: 41).

Raphael Hythloday is the main character of More's utopia and unlike Giles and More character who are actual people, he is entirely fictional. His first name Raphael has a reference to archangel name mentioned in Bible. Raphael was mentioned many times over Jewish mystical and apocalyptic literature as an Angel of healing not only of diseases but also of human spirit (Lasota, 2003: 42). The literal meaning of "Hythloday" is the "speaker of nonsense." Putting together these two names adds to the satirical purpose of More's writing.

In the Walled Garden of Truth, the poet meets an old man who comes from faraway land called the City of God. Like More's traveler, Sanai's old man is the only witness of that ideal society and readers become familiar with that place through his descriptions. 
"Like the moon before sunrise there suddenly entered

An old man saying "May God bless this morning!"

He was sweet tempered and of stable disposition,

Sharp-eyed and knowing well the climbing road

His face was like the sun, encrusted in light;

His robe was blue like robe of the celestial globe.

All at once, as it seemed, did emerge

A sun from the pond with the blue water-lilies. (De Bruijn, 1983:230)

Using specific character as the sole witness of utopia adds to the mystery and uniqueness of the story because as both authors emphasize not everyone can reach that place unless they have specific qualities and virtues.

Another main characteristic of both utopias is their geographical descriptions and their seclusion from the rest of the world. Utopia is usually an island that is difficult to find and only reached through accident or helpful guidance. The utopian island appears as an uncharted, distinct space in the midst of the ocean, while the ocean itself acts as the space through which time may distinguish itself from the regularity of everyday time and merge towards a utopian space of temporal distortion and manipulation (Cottrell-Smith, 2001: 4). Thomas More's island of utopia offers such characteristics. It has a half moon shaped that is surrounded by dangerous rocks. Access to the island is blocked by flooding rocks and only utopians know the exact locations of them. The geographical characteristics of island cause its isolation and speculation, it allows utopians to travel easily, but makes any sort of unwanted visit or attack from outside impossible. More's utopia has a close connection to real world. Susan Bruce (1999) in her work discussing three early modern utopias describes the island of utopia's characteristics as follow:

"Like British Isles, Utopia is an island; its main town and river resemble London and Thames, as contemporary commentators were quick to note. On closer investigation utopia becomes more a distorted reflection of the "real" England than its antithesis." (p.xxiv)

If More's utopia is depiction of a physical world, Sanai's utopia is inspired by spiritual world. Sanai calls his ideal city, the city of God; the place that is more similar to heaven than earth; however, like More's utopia, Sanai's the city of God is remote and secluded. This isolation and anonymity act as one of the important characteristics of Sanai's utopia. According to Hosseini (2010), The City of God refers to the world of immaterial bodies, the world of Forms and Utopia. Reaching Sanai's utopia like More's is not possible for everyone.

In Utopian works description is given priority over narration, that is, it literally eliminates narration: the plot, the action and the hero's adventures exist only before and after the utopian event, not in the course of it, because the utopian place is characterized by the suspension of the action and of time. One leaves the historical world to enter a parallel universe where everything is given and nothing changes. The utopian place is always described in minute detail, with an obsession for particulars that seem to have been set up in diametric opposition to the historical and geographical indeterminacy of reality (Fortunati \& Trousson, 2000:637). Utopia is described as a system of perfect social stability and equality as it is founded on the central ideal of man as a reasonable being in a community that nourishes everyone and cares for all (Festante, 2007:4).

More offers a detailed description of his ideal society through Hythloday's elaborate descriptions of utopia. Raphael Hythloday depicts the island as a natural paradise. Everything in island is designed to avoid conflicts and disagreements. In utopia, cities and houses have identical structure, all citizens' daily work hour is similar, and the island has common rules and laws. The citizens are well educated but the quality that is important is their virtue. In utopia group activities are promoted and privacy is discouraged. There are no locks on the doors, people wear similar clothes and the only versatility in clothing is due to the gender difference. Religious liberty is another characteristic of utopia. While reviewing all characteristics More offers for utopia, we can realize that his purpose was describing the perfect world in order to create a contrast against 'undesirable' society of England and Europe of that time. In first book, More writes about the problems of European society; then in second book he smartly present a society that doesn't face any of those problems.

There are fifty-four cities in the island, all large and well built: the manners, customs, and laws of which are the same, and they are all contrived as near in the same manner as the ground on which they stand will allow. The nearest lie at least twenty-four miles distance from one another, and the most remote are not so far distant but that a man can go on foot in one day from it to that which lies next it. Every city sends three of its wisest Senators once a year to Amaurot, to consult about their common concerns; for that is the chief town of the island, being situated near the centre of it, so that it is the most convenient place for their assemblies. The jurisdiction of every city extends at least twenty miles: and where the towns lie wider, they have much more ground: no town desires to enlarge its bounds, for the people consider themselves rather as tenants than landlords. They have built over all the country, farmhouses for husbandmen, which are well contrived, and are furnished with all things necessary for country labor. Inhabitants are sent by turns from the cities to dwell in them; no country family has fewer than forty men and women in it, besides two slaves. There is a master and a mistress set over every family; and over thirty families there is a magistrate (Utopia, 2007:44).

Just like More, Sanai is more concerned about presenting his utopia than writing a story. In the Walled Garden of Truth, most conversation between poet and the old man revolve around the characteristics of the city of God. 
"Its ground is not polluted by mud and fumes;

Its air is not tormented by heat and moisture.

The ground is as fat from having mountains and ditches

As the air is free from atmospherical disturbances.

The land of it is day and night increasing;

It is itself stable through all that it contains.

All that has found a place in that courtyard

Is animate, even the stones and the clods." (De Bruijn, 1983:23)

Descriptions Sanai offers for his ideal city gives reader a complete vision of what that place would look like. Old man describes the city as a place located between spiritual world (heaven) and materialistic world (earth). Tyrants have no place in that city and only virtuous people are allowed to live there. Prosperity and blessings are abundant and no one thinks about materialistic pleasures or wealth. The buildings are like palaces and the land is prosperous. Sanai describes his utopia as a prosperous land that is the source of all precious stones of the world. All valuables things in our world compared to that place, is worthless and unimportant. The mountains and soils are made of gold and jewels and its sea is filled with sweet water that tastes like honey. The city has white glorious and majestic palaces that portray purity of that place. All of these descriptions establish a place in our mind that is not similar to earthly cities and probably exist in another world or in heaven. The difference between More and Sanai's works is on the quality and nature of their places. While Thomas More's island is influenced by philosophical and political idealistic ideas, Sanai's description of utopian place is completely based on religious and spiritual concepts. The characteristics Sanai offers for the city of God is similar to the features Quran presents for Heaven. Islamic principles have great influence on Sanai vision for perfect world; therefore, he names his utopia, the city of God.

"He said: "when you join me, desiring to be guided,

Take anything I say to your soul;

A message from the First creature

To the last self-willed creature

Within this habit, the abode of your lament,

Why do you stay behind? Can you not tell me?

If for the sake of bread and water you stay on,

Why do you sow the seed of anger, lust and greed?

Your confusion only cards your chin (dishonors you)

And your fear only paralyzes you." (De Bruijn, 1983:232)

Another similar characteristic between Utopia and The city of God is that utopian ideas are presented through conversation among characters. This means that narrator already has visited the place and readers become familiar with his experience through the discussion he has with other characters. Utopia doesn't immediately appear as a whole but it is like a gradual discovery for the readers. The gradual process of portraying the ideal place is happened through narrators' conversation with other characters. Hythloday conversation with More in a garden one afternoon results in describing Utopia and The questions Sanai asks about the city of God and their conversation about reaching perfection signifies the characteristics of that place.

"After he had filled his eyes with my inner being,

He filled the casket of heaven to its gate with pearls,

Calling out "How dost thou fare, my son?

You who remained behind in this dungeon?

Arise! For this heap of dust is not your abode;

This is the home of desire; it is not your place!.." (De Bruijn, 1983:230)

Fortunti and Trousson (2000) also emphasize the important of discussion in narration; according to them, "the representation of the clash between the two worlds, the utopian world and the historical world, is operated by means of dialogue: the eminently dialectic literary resource through which differing points of view mix and meet head on." (p.7)

Utopian literature always tries to offer description of perfect society and its plot consists of the main character's journey and discovery of that land. The traveler is a character escaping from the society to which he belongs; he is an outsider capable of being different and then identifying with others and integrating. He represents the point of connection between two entities that could not communicate otherwise. His role as a mediator once again underlines the ambiguous relationship between Utopia and otherness: in order to be perfect (Fortunati \& Trousson, 2000: 639 ). We have the same sense of journey in both More and Sanai's work. The only difference is that Sanai's traveler is the citizen of utopian city 
and his journey can be considered "Journey from utopia" unlike More's traveler who visits the utopian island and his journey is "Journey to utopia".

The main concept of utopian society is that it is impossible to find in this world; therefore, authors create a place that doesn't exist in real life and its features are dreamlike. Thomas More's Utopia and Sanai's The Walled Garden of truth are connected to fantasy and dream. Both worlds were originated based on fiction and their characteristics are mythical and unreal. In this quality Sanai is much stronger than More, The world Sanai offers is completely visionary and dreamy. Sanai's city appears as fairyland and heaven to the readers. More approach toward fantasy is little different from Sanai, he mixes the realistic elements such as name of real people or real places that Hythloday traveled to, during his journey with the fictional elements of the utopian island. This method helps him to reach the satirical and ironical effect he intended completely.

\section{Conclusion}

Literary Utopia focuses on the story to present its author concepts, whether those concepts philosophical, religious or mythical, they are told through characters experiences and observations. More and Sanai, unintentionally both used the style of literary utopia in their work; therefore, we can observe following similarities in their writing style:

1-They both present their story through a narrator who is the only witnesses of the ideal land.

2- Both utopias are located in undisclosed location which is unknown to men and only those who are destined or in the case of Sanai's work, pure and mature enough can find it.

3- In both works, journey plays an important role, since it is the only way to reach their utopias.

4- More and Sanai gave priority to describing utopia over narrating story. Most part of their work is dedicated to the characteristics of their ideal land.

5- The stories in both works are presented through conversation (question and answer) among the narrator and the author himself as the second character.

6- And both utopias characteristics present a place that can only exist in dreams rather than reality.

Finally we can conclude that although Sanai's ideas were religious and inspired by Sufism and More's ideas were social and political, used to criticize England society and government of that time, they both used same style of writing and techniques to present their works. Their similar approach toward portraying ideal place puts both works in the category of literary utopia.

\section{References}

Asil, H. (1992). “Utopia in Iranian Thoughts”. (1 $1^{\text {st }}$ edition).Tehran: Ney Publication.

Beavis, M. A. (2006). Jesus and Utopia: Looking for the Kingdom of God in the Roman World. Fortress Press.

Bruce, S. (1999). Three Early Modern Utopias: Thomas More's Utopia/ Francis Bacon : New Atlantis/ Henry Neville: The Isle of Pines. London: Oxford University Press.

Bullock, M. (1992). The Walled Garden : A Fantasia. Canada: Ekstasis Edition.

Cottrell-Smith, C. (2012). "The Island Utopia and the Chronotope: Temporal Distortion in Utopian Fiction of the Renaissance". (1 $1^{\text {st }}$ edition). Bristole Journal of English Studies; Summer 2012.

De Brujin, J.T.P. (1983). Of Piety and Poetry: The Interaction of Religion and Literature in the Life and Works of Hakim Sanai of Ghazna. Brill: The University of Michigan University Publication.

Dragomir, S. (2011). “Utopia and New Atlantis, Utopia Revised”. Society and Politics Magazine; Vol.5, No.2 (10); November edition.

Festante, R. (2007). Utopia and Anti-utopia-A Comparison of Thomas More's Utopia and George Orwell's 1984. GRIN Verlang.

Fortunati, V., \& Trousson, R. (2000). Dictionary of Literary Utopias. Paris: Champion.

Gadens, D. (2002). Literary Movements for students: Presenting Analysis, Context and criticism on literary Movements. Indiana: Indiana University Press.

Ghaemi, F. (1386). “Types of Literary Utopia in Persian Classical Literature”. Professional Journal of Literature (Persian Language Journal); Fourth year; Fall and Winter 1386; volume 15 \& 16; 287-305.

Hertzler, J. O. (1922). The History of Utopian Thought. New York: MacMillan Company.

Hosseini, M. (2010). "Sanai and The City of God". Mytho-Mystic Literature Quarterly Journal (Persian Language and Literature Journal); Fall 2010; 6 (20); 45-64

Izadi L, Ameneh., \& Moghaddas, J. (2012). “ The Reflection of Sanaei’s Attitude to the Society Towards Humor, Satire and Parody in his Works” . Middle east journal of scientific Research; ISSN:1990-9233, pp.1116-1120.

Lasota, M. (2003). Archangel Raphael: Loving Messages of Joy, Love and Healing for Ourselves and our Earth. Lincoln: i universe.

Levitas, R. (2010). The Concept of Utopia. New York: Peterlang. 
More, T. (2007). Utopia. Rockville: Arc Manor LLC.

Ouseley, S.G., \& Reynolds, J. (1846). Biographical Notices of Persian Poets; with Critical and Explanatory Remarks. London: Oxford University Press.

Swanson, J.A., \& Corbin, D. C. Aristotle's Politics: A Reader's Guide. New York: Continuum.

White, F.R . (1955). Famous Utopias of the Renaissance. Hendric House.

Watson, K. (1994). “ Sir Thomas More Prospects: The Quarterly Review of Comparative Education”. Paris: Unesco, International Burea of Education. Vol. XXIV, No 1.2, pp.185-202.

Wegemer, G. (2001). Thomas More as Statesman: A Brief Sketchhttp.//Thomasmorestudies.org/docs/more_as_statesman.pdf 